\title{
The Charmed Life of Superstar Exporters: Survey Evidence on Firms and Trade Policy
}

\section{Citation}

Osgood, lain, Dustin Tingley, Thomas Bernauer, In Song Kim, Helen V. Milner, and Gabriele Spilker. 2017. "The Charmed Life of Superstar Exporters: Survey Evidence on Firms and Trade Policy." The Journal of Politics 79 (1): 133-52. https://doi.org/10.1086/687207.

\section{Permanent link}

http://nrs.harvard.edu/urn-3:HUL.InstRepos:38057815

\section{Terms of Use}

This article was downloaded from Harvard University's DASH repository, and is made available under the terms and conditions applicable to Other Posted Material, as set forth at http:// nrs.harvard.edu/urn-3:HUL.InstRepos:dash.current.terms-of-use\#LAA

\section{Share Your Story}

The Harvard community has made this article openly available.

Please share how this access benefits you. Submit a story.

Accessibility 


\title{
The Charmed Life of Superstar Exporters: Survey Evidence on Firms and Trade Policy
}

\author{
lain Osgood, University of Michigan \\ Dustin Tingley, Harvard University \\ Thomas Bernauer, ETH, Zurich \\ In Song Kim, Massachusetts Institute of Technology \\ Helen V. Milner, Princeton University \\ Gabriele Spilker, University of Salzburg
}

What factors determine firms' attitudes toward trade policy? This paper considers producers' policy preferences and political behavior in light of two key patterns in modern international trade: industries that face import competition often have many exporters, and foreign sales are concentrated in the hands of a small number of "superstar" exporters. Using a new survey of Costa Rican firms matched to systematic firm-level data on export behavior, we find that firm features are generally more important predictors of attitudes toward trade liberalization than industry-wide comparative advantage. We also show that export intensity is strongly associated with interest and lobbying activity on trade policy. The largest exporters, who are the strongest supporters of global integration, dominate trade politics.

W hat factors determine firms' attitudes toward trade policy? And how do firms' characteristics shape their level of engagement and lobbying activity in the political process, where trade policy gets made? Reflecting the turn toward firms in the economics of trade, this paper provides an account of producer preferences over trade policy emphasizing two factors: the large numbers of exporters in "import-competing" industries and the overwhelming domination of foreign sales by a small number of "superstar" exporters. These two factors are used to develop a series of predictions about how firm, rather than industry, characteristics shape attitudes toward trade liberalization and determine levels of political engagement on trade policy. These ideas are tested on a survey of Costa Rican firms matched to firm-level data on export performance.

Our theory builds off of a small but growing literature on firm heterogeneity and trade politics, to which we contribute in three closely related ways (see, e.g., Kim 2014b; Osgood
2016; Plouffe 2012). First, we focus on the political implications of the concentration of export sales in the hands of a small number of highly successful "superstar" exporters (Freund and Pierola 2012; Mayer and Ottaviano 2008). These firms are the core constituents for trade liberalization, and their enormous share of export sales give them the incentive, intensity, and resources to supercharge their protrade political activity. The remainder of firms - who are not winners from liberalization - are, in contrast, small in size and many in number, and they face costs diffused over a broad range of firms. Second, we emphasize how product differentiation provides opportunities for these superstar firms to export even in industries facing sharp import competition, turning them into a fifth column in support of greater trade liberalization. Finally, we argue that each of these patterns together gives trade policy in the modern era of intra-industry trade and industrial concentration a strongly pro-globalization bias. Support for trade coincides precisely with the political advantages

Iain Osgood (corresponding author; iosgood@umich.edu) is an assistant professor of political science at the University of Michigan, Ann Arbor, MI 48104. Dustin Tingley is a professor of government at Harvard University, Cambridge, MA 02138. Thomas Bernauer is a professor of political science at ETH Zurich, Switzerland. In Song Kim is an assistant professor of political science at MIT, Cambridge, MA 02142. Helen Milner is the B. C. Forbes Professor of Politics and International Affairs at Princeton University, Princeton, NJ 08544. Gabriele Spilker is an assistant professor of political science at the University of Salzburg, Austria.

Data and supporting materials necessary to reproduce the numerical results in the paper are available in the JOP Dataverse (https://dataverse .harvard.edu/dataverse/jop). An online appendix with supplementary material is available at http://dx.doi.org/10.1086/687207. 
of size and concentration, even as the opponents of trade liberalization are undermined from within their own ranks.

We bridge the gap between our theoretical contributions and our country case study, Costa Rica, by providing evidence of each of our scope conditions using a comprehensive firm-level data set on annual export sales for nearly all Costa Rican exporters. Firm-level transaction data on exporting are generally scarce; matching these data to our survey on political preferences therefore provides a unique opportunity. We show that export sales are highly skewed toward the most successful exporters and that net-importing industrieseven industries where imports are many times greater than exports - still have significant numbers of exporters, some of whom are highly successful. These are precisely the industries that would be considered at a "comparative disadvantage" and assumed united in opposition to trade liberalization - in the standard "specific factors" account of trade politics (Alt et al. 1996).

We then turn to testing our predictions. We expect to see firm-level characteristics - export status, and especially exportintensity - to be positively correlated with support for trade liberalization. If the emphasis on firm performance and product differentiation is merited, these effects should hold even conditional on industry-wide measures of comparative advantage. This is a sharp contrast with the specific factors model, where an industry's trade orientation determines the attitudes of all firms in the industry, regardless of whether any particular firm exports or not. We also examine the political ramifications of firms' trade policy preferences: we show the positive impact of the scale of firms' exports on their beliefs that trade policy is important, on their willingness to seek information about trade policy developments, and on their lobbying activity. Pro-trade firms have the most intense preferences and have the financial and political capital to see those preferences realized as policy.

We find support for each of these propositions using an original survey of firms located in Costa Rica. ${ }^{1}$ The focus on a highly successful and growing, but nonetheless developing, country enables us to ask whether the findings on firm heterogeneity and politics in Osgood (2017) and Plouffe (2012), which examine developed country cases, travel to a developing country context, while matching our survey results to a rich, firm-level export data set. We find that they do.

1. For other examples of firm-level surveys in international political economy, see Büthe and Mattli (2011), Kenyon and Margalit (2014), Kuno and Naoi (2015), and Mosley (2003). We later describe the substantive and pragmatic considerations that led us to focus on trade politics in Costa Rica.
The structure of our paper is as follows. The first main section brings together the various theoretical models developed in the literature and highlights their key predictions. We then introduce our firm-level survey data, which features responses from over 260 Costa Rican firms, and this is followed by our findings. We find strong evidence for the two core predictions of the "new, new trade theory for the politics of trade": firm attributes, especially size and export capacity, are stronger predictors of trade attitudes than the industrywide predictors usually emphasized. The implications of these findings for firms' preference intensity and political engagement on trade issues are then examined. We conclude by highlighting opportunities for further research.

\section{THEORY Intra-industry trade and firm heterogeneity}

Until now, the study of trade politics has been dominated by two competing models. While generating starkly different predictions about coalitions on trade policy, the StolperSamuelson and Ricardo-Viner approaches have two crucial analytic similarities. First, both approaches rely on the idea of shared prices creating shared interests. In the Ricardo-Viner model, trade alters goods prices shared among all firms in the same industry, and these price changes directly determine attitudes. In the Stolper-Samuelson approach, trade alters factor prices shared by all owners of the same factor, and these factoral price changes determine attitudes. ${ }^{2}$ Second, both approaches gloss over differences among firms, in particular heterogeneity in productivity, scale, and export engagement. Industries are assumed to be composed of identical producers who naturally share identical interests.

Two developments in the economics of trade over the past few decades suggest that these assumptions form a questionable basis on which to build our theories of trade politics. The first of these is the discovery that intra-industry trade, where a country both imports and exports a good at the same time, is widespread (Brülhart 2009; Grubel and Lloyd 1971). The second is the discovery that firms differ sharply in the extent to which they are able to engage export markets, even within the same narrowly defined industry (Bernard and Jensen 1995). In most industries, only a minority of firms usually export and an even smaller share of those firms control the bulk of all exports sales (Mayer and Ottaviano 2008).

Intra-industry trade occurs where two countries mutually exchange varieties of essentially the same product, making both trade partners simultaneously export- and import-

2. Both models feature both goods and factor price changes, of course. The key distinction is whether factor price differences are arbitraged away due to inter-industry factor mobility. 
competing (Grubel and Lloyd 1975). Such trade is generally the result of a taste for product variety either within or among consumers - wine and automobiles, for example, feature significant intra-industry trade. Models of intra-industry trade usually assume that firms monopolize the production of particular brands or varieties (Helpman 1981; Krugman 1980). This gives firms some measure of power to set prices (Dixit and Stiglitz 1977; Lancaster 1979).

The first generation of trade models featuring intraindustry trade assumed that all firms were identical in size and productivity (Helpman and Krugman 1985). Despite their newfound ability to set different prices for their unique varieties, equilibrium prices (and sales) among firms in the same industry remained the same. With the rise of quality firm-level data sets on export engagement and sales, however, scholars discovered that even in the most export-oriented industries, only a (generally small) minority of large, successful firms actually enter and remain in export markets (Bernard and Jensen 1995, 2004; Bernard et al. 2007; Tybout 2003). This is usually explained with reference to productivity differences among firms. Only the most productive firms, which can profitably sell at the lowest prices, can pay the significant fixed and variable costs associated with accessing foreign markets and still profit from trade.

This firm heterogeneity in productivity broke the common price equilibrium among firms in models of intra-industry trade. In equilibrium, more productive firms have lower prices. They are therefore able to find positive demand for their varieties abroad even on top of trade costs. Less productive firms generally must charge higher prices in order to recoup their higher costs, and they therefore are less likely to find export markets for their relatively expensive products once trade costs are included (Bernard et al. 2003; Melitz 2003; Melitz and Ottaviano 2008). Returns to capital in these models therefore differ not only across industries but within industries, with larger producers earning greater profits due to their superior performance both at home and abroad. We describe the distributive impacts of trade liberalization more fully below.

The burgeoning literature on firms and trade has recently focused on an important aspect of firm heterogeneity that was not fully appreciated in the earliest empirical studies: export sales are highly skewed toward a few highly successful producers (Bernard et al. 2007; Malmberg, Malmberg, and Lundequist 2000; Mayer and Ottaviano 2008; Muûls and Pisu 2009). For example, in 2000 , around $18 \%$ of US manufacturing firms exported, and about $3 \%$ of all firms overall including nontradables (Bernard et al. 2007; Bernard, Jensen, and Schott 2009). However, among all firms that exported, the largest $1 \%$ (about 1,700 firms total) accounted for $80.9 \%$ of all US exports (Bernard et al. 2009).
At this point, we now have the two crucial ingredients for describing a theory of firm preferences over trade (Osgood 2016). On the one hand, because of product differentiation, industries are both import- and export-competing at the same time. Consumers, wishing to maximize product variety, must look abroad, even if foreign producers have higher costs or prices, in order to access the unique varieties monopolized by foreign producers. This logic is symmetrical across countries, thereby generating the two-way trade that is so characteristic of post-war international trade. Second, firms differ in their ability to access foreign markets, and therefore they differ in their ability to benefit from trade liberalization. In industries with differentiated products, then, all firms face greater import competition in the wake of trade liberalization, but only an elite few are able to successfully export. $^{3}$

\section{Distributive impacts of trade liberalization}

The combination of product differentiation and firm heterogeneity gives rise to sharply different distributive implications associated with trade liberalization than those predicted by the standard trade model (Melitz 2003). In the standard trade model, all firms producing the same product win or lose together. Industries featuring differentiated products, in contrast, witness sharp intra-industry reallocations of profit in the wake of trade liberalization (Aw, Chung, and Roberts 2000; Berthou and Vicard 2015; Eaton et al. 2007; Girma, Greenaway, and Kneller 2003; Pavcnik 2002). The most productive firms increase profits from trade liberalization, on net, while the least productive firms lose profits or drop out altogether. ${ }^{4}$

These intra-industry redistributions are easily understood by examining the trade-offs associated with reciprocal trade liberalization for a set of firms producing varieties of a differentiated product (Melitz and Ottaviano 2008). The first major impact of trade is that it means greater competition from abroad. Home market consumers wish to diversify their

3. One interesting question raised by the notion of product differentiation is whether products might become so variegated that they are effectively no longer substitutes. In part, this is a question of aggregation and the appropriate level of analysis. When we speak of industries producing differentiated products here, we generally mean industries where products remain partially substitutable.

4. On firm exit, Pavcnik (2002) studies the massive unilateral cuts in trade barriers undertaken by Chile from 1979 to 1986, documenting significantly greater exit among less productive plants in the wake of the liberalization. On productivity and exporting, Aw et al. (2000) and Wagner (2007) use country-level panel studies to argue that the link between productivity and exporting is primarily driven by the self-selection of highly productive firms into export markets. 
consumption by importing more foreign varieties once trade barriers have been lowered. This will occur even if foreign producers have higher prices, on average, than home market producers, illustrating how product differentiation breaks the ordinary logic of comparative advantage and one-way trade. Trade liberalization therefore imposes a significant cost on all producers - displacement by foreign firms and so lost profits - even if the foreign country is at a comparative disadvantage.

The second major impact of reciprocal trade liberalization is, of course, that it creates new opportunities for exporting. This is true for both extant exporters, who can expand the scale of sales in markets they already serve when trade barriers drop, and for new entrants to the export market. However, because exporting imposes significant fixed and variable costs, only firms selling at the lowest cost (or at the greatest scale) will be among the ranks of those exporters whose foreign sales increase in the wake of liberalization (Das, Roberts, and Tybout 2007).

So far we have a clear set of distributive implications for nonexporting firms. Trade liberalization, even with a less competitive country, is always a negative because it means greater competition and reduced profits. But that does not imply that all exporting firms will benefit from trade liberalization. Consider the impact of trade liberalization on a marginal exporter who just barely earns a positive profit from exporting. This firm will still face significant lost profits from trade liberalization due to extra competition in the home market from foreign producers. A key theme that has emerged in the most recent empirical literature on firm performance in export markets reinforces this point. Even among exporters, the vast majority of export sales are concentrated in the hands of a relatively small number of "superstar" firms (Bernard, Van Beveren, and Vandenbussche 2014; Mayer and Ottaviano 2008). This means that the biggest winners from globalization may be a relatively small group of large highvolume exporters.

\section{Firm attributes and attitudes toward trade liberalization}

This discussion therefore suggests a first proposition linking firm attributes and support for trade liberalization.

Prediction 1. Exporting firms are more likely to support reciprocal trade liberalization holding constant the comparative advantage of their industry as a whole, though marginal exporters may not support trade. Because larger firms reap the greatest rewards from liberalization, the extent of exporting should be positively correlated with support for freer trade.
The first part of this prediction is straightforward. All firms face greater competition in the wake of multilateral trade liberalization, but only a subset of exporting firms have the opportunity to increase profits through exporting (see, e.g., Kim 2014b; Osgood 2016; Plouffe 2012). Support for trade will therefore be higher, on average, among those firms that export even if the smaller among them gain relatively little, or even lose, from liberalization. While the claim that "exporting firms support trade" may sound obvious, it is important to note how sharply this differs from the RicardoViner approach, where the key factor is whether the industry's good is exported. Whether a particular firm is exporting that commodity-type good is irrelevant to its bottom line because it still benefits from an increase in price. ${ }^{5}$ If our approach is substantiated, then coalitions in favor of trade liberalization ought to cut across industries, knitting together the largest exporting firms regardless of whether the industry is net-exporting or net-importing. This is, then, a distinct alternative to the two images of trade politics coalitions described in Hiscox (2002).

The second part of this prediction requires that we condition on some proxy for the comparative advantage of a firm's industry. Among a sample of firms, a simple correlation between exporting and support for trade might be confirmation of either the "new, new trade" approach or the specific factors model, and so it provides no analytical traction for comparing the two models. Our approach is to hold constant the overall industry orientation to trade, whether netimporting, net-exporting, or something closer to neutral, and examine if the export status of the firm still has predictive power. If the specific factors model is correct, the export status of a particular firm should have no explanatory power once its industry has been correctly identified as net-exporting. Moreover, the export status of a firm should be a weak predictor of support for trade in any event, because even nonexporting firms can benefit from trade liberalization in the standard trade model. If, on the other hand, exporting, and especially export intensity, are consistently strong predictors of support for trade, over and above the export orientation of the industry as a whole, then a firm-centered approach is supported.

The third part of our first prediction - that the extent of exporting should be as important, if not more so, than simply being an exporter-builds off of the new focus on "superstar" exporters. A simplistic rendering of the new, new

5. The departure from a Stolper-Samuelson approach, where it does not even matter if the firm's industry's good is exported at all, should be even clearer. 
trade theory's implications for trade politics would be that exporters support trade and nonexporters do not. We emphasize here that not all exporters are created equal, and we expect the staunchest support for globalization to be at the highly successful top end of the export distribution. Another way of putting this is that a focus on the extensive margin of exporting (do firms exports or not?) can obscure a lot of difference along the intensive margin of exporting (how much does each firm export, and how does that vary among firms?). Unpacking the political interests and activities of exporting firms may be just as important as unpacking industries themselves.

Before moving on, we discuss two additional issues about translating our predictions into empirical models. First, we again highlight a key scope condition of our model of firms' preferences: that the product be differentiated so that there is a potential for firms to export even in "import-competing" industries. The reach of our theory is limited to industries with some measure of product differentiation, and we would expect that where products are entirely homogeneous an industry's preferences over trade would look like the the Ricardo-Viner predictions, that is, driven by industry-level factors rather than firms' ability to export. In practice, we find that some of the industries in Costa Rica with relatively homogeneous goods, according to the best available measures, still have exporting firms and still have intra-industry trade. For this reason, and due to our restricted sample size, we pool the data in our main analysis and leave our first prediction unconditional. However, we explore the conditional effects of firm- and industry-level factors on support for trade in the appendix, available online.

Second, we also note that significant literatures have emerged emphasizing intra-industry variation in the sourcing of inputs from abroad and in multinational activity. While not the focus of the theoretical development here, these differences of course provide alternative explanations for why larger firms might support trade liberalization since globalization of the supply chain is only available to the largest firms (Antras and Helpman 2004; Bernard et al. 2009; Girma and Görg 2007; Greenaway and Kneller 2007; Tomiura 2007). We first note that our main measure of support for trade asks about liberalization "in your industry," so we do not think (and do not find) that response is driven by opportunities to source inputs. Second, much multinational activity is horizontal in nature, so the relationship between multinational status and support for own-industry liberalization may not be strong. Third, to give these alternative explanations their full due (and to ensure that the posited links between export ability and other aspects of globalization are not spurious), we condition in all models presented on measures of whether the respondent is an importer of intermediate goods and is a part of a multinational firm.

\section{Preference intensity and political engagement}

According to the dominant models of trade with heterogeneous firms, the distributive impact of trade liberalization varies continuously through the productivity distribution of firms. In the simplest version of this story, the least productive firms lose from trade liberalization (and may even shut down altogether); marginal exporters will lose or gain, on net, very little from trade liberalization; and, at the top end, a group of highly productive exporters reap outsize gains from trade liberalization (Melitz 2003).

These distributive consequences suggest that interest in trade politics will be concentrated in the upper reaches of the productivity distribution (Kim 2014a). Recall that export sales are heavily concentrated in the hands of the largest exporters. So, in industries producing differentiated products, liberalization might create no gains whatsoever for the bulk of firms but lead to increased competition that is broadly diffused across the set of all firms. A small minority of highly successful exporters are therefore likely to be strong and active proponents of trade liberalization. In contrast, the large remainder of modestly sized producers share the losses from trade across many firms, so each firm's losses from trade are small in both absolute and relative terms. For this reason, trade's opponents lack the vehemence of trade's staunch supporters. Note also that these small- and mediumsized firms are partially buffered from competition because, despite their inefficiency, they are the sole producer of the variety they monopolize (Krugman 1981; Rodrik 1995). Given these conditions, the benefits of trade liberalization are concentrated on the pro-trade side, while the costs are broadly diffused, inverting the usual formula used to explain trade protectionism (Alt and Gilligan 1994; Wilson 1974).

These ideas lead to a second prediction.

Prediction 2. The largest exporters will consider trade policy to be a much more significant issue than either smaller exporters or nonexporters. This preference intensity will also manifest itself in patterns of informationseeking and lobbying on trade policy, where we expect the largest firms to be most active.

A potential alternative explanation for the pattern outlined in prediction 2 might be that smaller firms, though identifying trade as salient, are disengaged politically due to a perceived or actual inability to influence government. This might be because they consider themselves too small to effectively make their case before policy makers because they 
find the organizational challenges associated with effective lobbying too daunting or because they simply lack the financial and political capital to undertake a successful lobbying effort. ${ }^{6}$ We consider this alternative by considering evidence of both preferences, which should not face financial or organizational constraints, and lobbying behavior, which certainly does. In practice, it is likely that both channels are operative. In the next section, we describe the data we collected to test our predictions.

\section{DESCRIPTION OF THE DATA}

While there is some existing work on firms in international political economy (e.g., Hathaway 1998; Milner 1988), relatively few attempts have been made to systematically survey firms (examples include Büthe and Mattli [2011], Kenyon and Margalit [2014], Kuno and Naoi [2015], Malesky and Taussig [2009], Mosley [2003], and Samphantharak and Malesky [2008]). We add to this firm-level survey literature both by focusing on responses to questions about trade preferences and political engagement and by testing predictions that move beyond standard factoral- or sectoral-based explanations. These predictions are tested on a survey of firms located in Costa Rica that was fielded in two waves, from November 2013 to February 2014 and then from May to June 2014. Firms were presented with a large survey of questions about the impact of globalization on their firm and industry, their political activities, and the operation of their business.? We discuss the specific questions used for this paper below, where we introduce our main variables, and for now we introduce the country setting and describe the match between our sample and the population of firms in Costa Rica.

Costa Rica provides a valuable case for the study of firm attitudes toward trade policy for reasons both substantive and practical. On the substantive side, Costa Rica provides an ideal environment to examine the impacts of trade liberalization across a wide variety of industries and firms. Costa

6. On lobbying and collective action around trade, see Alt and Gilligan (1994), Busch and Reinhardt (2000), and Gawande and Bandyopadhyay (2000). We also note at this point that heterogeneous preferences will tend to defeat the ordinary channel for small firms to influence their government via their trade association. This is especially true if associations are dominated by their largest members at the expense of small- and mediumsized enterprises, as argued in Bennett (1998), Bennett and Robson (1999), and Huggins and Johnston (2010).

7. The second wave of the survey was shortened primarily by removing a set of questions about firms' financial operations and some other openended response questions. This was done to avoid attrition and to make an accurate promise of completion in under 10 minutes to entice response in the second wave. All variables included in this paper were included in both waves of the survey. We did not find heterogeneous effects of our main explanatory variables across survey waves.
Rica is a rapidly growing, globalizing, and developing country and is currently in accession talks with the Organization for Economic Cooperation and Development (OECD). While historically Costa Rica has exported mainly agricultural commodities, its export profile has diversified significantly over the past two decades into both basic and advanced manufacturing (agriculture now accounts for only 6\% of Costa Rican gross domestic product [GDP]). In 2013, export volumes were around $35 \%$ of Costa Rica's GDP, and manufacturing accounted for $62 \%$ of all merchandise export sales (World Bank 2013). Food and animals have accounted for only $14 \%$ of exports. Costa Rica has also significantly increased the exposure of its own firms to international competition. Citing Paus (2005), Cordero and Paus (2008) report that average tariff rates fell from above $60 \%$ to $5.8 \%$ between 1985 and 2004. While the implementation of CAFTA (Central America Free Trade Agreement) in 2009 was a key milestone, Costa Rica has since 2010 signed preferential trade agreements with China, Singapore, Mexico, and the European Union. China, Mexico, and the European Union are all among Costa Rica's five greatest trade partners (Hausmann et al. 2014). Costa Rica is also a major recipient of foreign direct investment (FDI), and in 2014, its total stock of inward FDI was equal to $50.5 \%$ of Costa Rican GDP (UNCTAD 2015).

These enormous changes reflect a concerted and frequently controversial strategy of neoliberal reform begun in the wake of International Monetary Fund and World Bank interventions to stabilize and reform the Costa Rican economy during the Monge administration, which was accelerated by President Oscar Arias during his first term in office, 1986-90 (Cordero and Paus 2008). Since these reforms, Costa Rica has aggressively pursued free trade agreements and bilateral investment treaties, which has sparked considerable debate within the country (Hicks, Milner, and Tingley 2014).

Costa Rica has a lively associational politics (77.9\% of our respondents report being in a trade association), and trade associations exist across the manufacturing, agriculture, and service sectors, whether import- or export-competing. These industry associations are complemented by several peak associations; the Costa Rican Chamber of Exporters (CADEXCO) is especially active on trade issues. Lobbying is also commonplace: $35.9 \%$ of our respondents reported contacting the Office of the President, the Legislative Assembly, or the Ministry of Foreign Trade (COMEX) to discuss public policy. Electoral campaigns in Costa Rica are funded both publicly and privately, though private funds make up the majority. Relatively large limits on individual contributions and recurring scandals associated with campaign giving have created an impression that big business and the wealthy dominate campaign financing (AAACP 2004; Casas-Zamora and Zovato 2015). 
How is trade policy made in Costa Rica? Trade agreements are generally negotiated by the executive branch, with close coordination between the Office of the President and the Ministry of Foreign Trade (COMEX), which generally takes the lead in formulating policy as well as international negotiations (WTO Secretariat 2013). Trade agreements are generally then subject to a vote by the unicameral Asamblea Legislativa, although, exceptionally, the CAFTA agreement was approved by general referendum (see Singh [2005], citing Echandi [1997]). COMEX also plays a significant role in administering Costa Rican trade rules and in export and investment promotion, for example, by funding and advising the Procomer export promotion agency. Policy making in Costa Rica also features extensive communication between the government and relevant industrial stakeholders: $28 \%$ of our firm respondents reported contacting one of the above institutions about issues relating to international trade or outsourcing.

Costa Rica therefore provides a rich political environment for the study of trade politics: it is a successful, diversified, and increasingly globalized upper-middle-income country; this global engagement - and increases in trade especiallyhas apparently contributed to impressive economic growth, but it has also sustained special interest engagement and public controversy.

On the practical side, Costa Rica has several key resources that we make use of for this research. First, the Costa Rican government created a public quasi-independent agency in 1996, Promotora del Comercio Exterior de Costa Rica, or Procomer, which gathers data on virtually all Costa Rican firms that export, including information on the quantity, product categorization, and destination of all export sales on an annual basis. We make extensive use of these data in our project, as described below. Second, Costa Rica has a number of governmental and nongovernmental institutions that are experienced in the administration of firm-level surveys and that gather data on firm contact information.

To conduct our survey of Costa Rican firms, we partnered with INCAE, the leading business school in Costa Rica. We developed a list of potential firms and contact information using several sources, including Procomer. In total, we sent e-mails that contained a link to an online survey to 2,577 firms. The survey introduced the researchers and their affiliations and indicated that the survey's objective was to better understand firm opinions concerning international trade. The survey was translated from English to Spanish by a native Spanish speaker and was checked for back translation separately.

Our total number of respondents was 389 , leading to an overall response rate of $15.1 \%$. Our response rate among
Procomer firms was $15.07 \% .^{8}$ Among these respondents, 268 fall within the agriculture, mining, and manufacturing sectors, for which trade is most relevant, and we examine only these firms in our models. ${ }^{9}$ These correspond to all ISIC Revision 3.1 codes 01-37 (International Standard Industrial Classification of All Economic Activities). While this is a modest overall response rate, this number provides sufficient statistical power for our main tests, and we believe that it represents important data on the attitudes of firms toward globalization in an open developing economy. We describe the match between our sample and the population of exporting firms in Costa Rica below.

The response rate varied somewhat depending on the question in the survey, mainly because of attrition toward the end of the survey and occasionally because of nonresponse. ${ }^{10}$ For example, our main question about support for trade liberalization received 256 responses (out of 268 possible), while our question about importing, which comes toward the end of the survey, received only 216 responses. In order to handle this nonresponse and take maximal advantage of the data, we create 10 imputed data sets using software described in Honaker, King, and Blackwell (2009). All models are estimated using software from Imai, King, and Lau (2008) and are recombined according to the formulae in Rubin (2004). Imputation is generally preferred to ad hoc strategies, such as listwise deletion, but we also replicate all of our main findings using the original data and find that our main results are quite similar. These models are contained in appendix $\mathrm{D}$, available online.

The imputation of missing data is generally only justified under an assumption that the missingness is at random, that is, that the probability of missingness is a function of observed covariates and not of the missing outcomes themselves, conditional on observed covariate values. We believe it likely that some of our nonresponse is completely at random: respondents may have simply not known the answer to questions or may have dropped out of the survey for idiosyncratic reasons. If this is not the case, we include in our imputation model a rich set of industry- and firm-level covariates that are fully observed, and we note that many of our most important variables are observed in the vast majority

8. We have not counted respondents who began the survey but did not answer it in these figures. We also received responses from two Procomer firms that we could not match to firms in our original panel of contact information. We have included these respondents in the analysis.

9. The Procomer data do not include export information on firms in services and other nonagriculture, nonmining, and nonmanufacturing industries, and international trade data on those industries are not available in any event.

10. Per our IRB (institutional review board), we could not "force" responses to questions. 
140 / Superstar Exporters: Survey Evidence on Firms and Trade Policy lain Osgood et al.

of cases. We think it is plausible that nonresponse to particular questions and attrition are predictable by our observed firm and industry characteristics and by observed answers to other survey questions. For example, if dropout on our survey about globalization is correlated with firm export sales or industry export or import competition, then we have those factors measured and included in the imputation model. ${ }^{11}$ Finally, we do not attempt to systematically handle nonresponse to the survey at the population level. Our imputation strategy is focused solely on handling nonresponse and dropout among those who responded to the survey.

\section{Sample characteristics}

This section interrogates the characteristics of exporters in our sample compared to information about the universe of exporters. While we show a number of desirable characteristics, we briefly mention some limitations. Around 27.8\% of our agriculture, mining, and manufacturing respondents report operating foreign production facilities and $84 \%$ exported at some point from 2000 to 2012, indicating that we had a relatively large number of multinational firms and exporters in our sample. ${ }^{12}$ These figures may simply reflect that Costa Rica is a small open economy that has higher rates of export than, for example, the relatively insular and large United States, or that exporters were more likely to respond to a survey associated with the Procomer agency. Note also that the Procomer data include all firms that even tentatively exported in very small volumes, so some of our respondents are neither currently active exporters nor do they export in significant numbers. Among our respondents, average annual export sales for the median firm are $\$ 27,000$, and average annual export sales do not exceed a million dollars until the 88th percentile of firms within our sample. This enormous heterogeneity in export participation is precisely the reason that we focus on the extent of exporting in our theory and data analysis. Moreover, because we condition on multinational status and some measure of export activity in all models - and are not focused on estimating population-level quantitieswe see our potentially higher response rate among exporting and multinational firms as an advantage, improving the estimation of differences between exporters and nonexporters or between multinationals and nonmultinationals.

Appendix A provides a detailed analysis of how our sample compares to the set of all exporting firms in Costa Rica

11. All predictors and outcomes employed in this paper are included in the imputation model.

12. Among our respondents, $84 \%$ fall into the Procomer umbrella, indicating that they exported at some point over the period 2002-12. Around $64 \%$ of the respondents were active exporters in 2012, and 57\% were active in all three years of 2010-12. using data from Procomer. We check the match between our sample and the complete population for several key variables that are subsequently used in the analysis. Our results show substantially similar distributions across exporters in our survey and those that did not respond to our survey, suggesting that our respondents are broadly representative of Costa Rica's population of firms as a whole. We also examine in detail the sectoral distribution of firms in our sample across 2-digit ISIC industries, and again we find that our sample has desirable properties.

\section{Skewness of export sales and intra-industry trade in Costa Rica}

In order to build a bridge between the theory and our rich firm-level data, in this subsection we demonstrate that the two key analytic factors emphasized above in our theoretical development are operative within our country case, Costa Rica. In other words, the key premises of our theory are valid for the case we examine.

Figure 1 demonstrates the extraordinary skewness of exports sales within Costa Rica, confirming that the pattern noted in several other country studies above is also present within our case. The top $1 \%$ of exporting firms control on average $53 \%$ of export sales across all industries (this figure is $59 \%$ if industries are weighted by total export sales). The top $10 \%$ of exporters control more than $80 \%$ of all exports in 24 of 27 industries examined. For the country as a whole, the top $1 \%, 5 \%$, and $10 \%$ of firms account for $62.7 \%, 87.6 \%$, and $94.5 \%$ of all export sales, respectively. We take these data as evidence that our country case will provide fertile ground for examining the impact of export concentration, and of firm heterogeneity more generally, on trade politics.

The Procomer data also reveal that the set of Costa Rican firms that export is in a state of constant flux and that most firms that export do so tentatively and do not succeed over the long run. Some 37.4\% of new entrants from 2001 to 2009 did not export at all in the three years after their initial entry into export markets. A further $71.6 \%$ that exported in a second year dropped out in the two years thereafter. Overall, 74\% of new entrants from 2001 were not active in 2012. More broadly, a significant number of firms drop in and out of export markets recurrently, exporting only intermittently over the span of our data. These patterns, and the heterogeneity documented in figure 1, amply illustrate just how sharp the differences among exporters can be. They also help to explain why such a high proportion of our respondents fall into the Procomer umbrella at some point.

Figure 2 considers our other main theoretical factor: the high volume of export sales in "import-competing" industries. Each dot represents a 4-digit ISIC Revision 3.1 industry. 


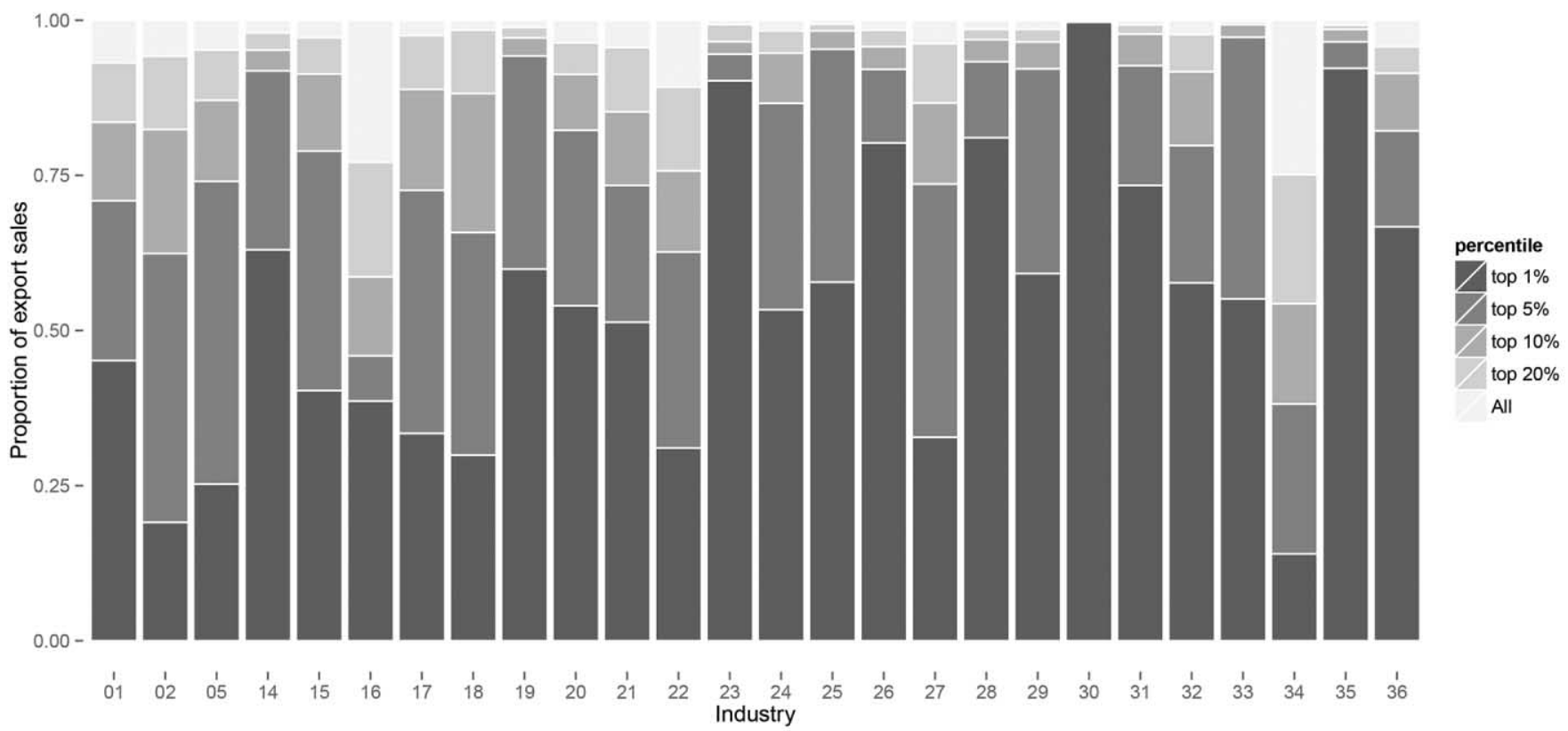

Figure 1. This figure shows the proportion of all export sales from 2000 to 2012 accounted for by the largest 1\%, 5\%, 10\%, and 20\% of Costa Rican firms. Exports sales are highly skewed toward the largest exporters. Only industries containing at least 25 firms in the Procomer data are included.

Along the horizontal axis we report that industry's exportto-import ratio. ${ }^{13}$ Industries significantly above 1 export far in excess of any import competition, industries significantly below 1 are heavily import-competing, and industries near 1 are exemplars of intra-industry trade flows. While there is a negative correlation between net trade and the number of exporting firms, it is striking how large the number of exporting firms is even in industries that fall well within the net-importing range. This is true even at extremely low export-import ratios. In our rendering, these firms are potential winners from trade liberalization, even if the other firms in their industry are threatened by greater trade.

The bottom half of the figure reinforces this point by considering the total export sales of the most successful exporters over the years 2000-2012. Even in industries that are quite import-competing (i.e., near .01 on the horizontal axis and beyond), there are still individual firms that exported in enormous quantities over this time span. This, again, suggests the importance of firm monopolies of differentiated products and that there are winners from trade liberalization even in "comparative disadvantage" industries. In the next section, we show that these apparent winners are indeed supporters of trade.

13. This scale is cut off at a ratio of $1: 1,000$, and industries with no exporters whatsoever are given a value of .0001 , so they are included in the figure as points in the lower left-hand corner; 23 of 140 4-digit ISIC industries are located at these points with no export sales in each figure.

\section{RESULTS}

The core empirical results in this paper are now presented. Summary statistics for all variables are provided in table 1. First, we examine support for trade liberalization among our survey respondents. Firm-level factors, especially export activity and intensity, are strongly predictive of support for trade liberalization, while various proxies for industry-wide comparative advantage are not. Then we examine the links between firm- and industry-level variables and a set of questions on firm interest in, and lobbying on, trade politics. A very strong pattern emerges: only the largest and most successful exporting firms consider trade politics to be worthy of interest and expending their political capital. Export status alone does not generate such interest, but a high intensity of export participation does.

\section{Firm characteristics and support for trade}

The models reported in table 2 demonstrate that features of firms, over and above characteristics of their industries or the goods they produce, explain attitudes toward trade liberalization. Our survey asked: "Overall, do you believe that mutual reductions of international trade barriers in your industry, agreed on by Costa Rica and other countries in the past few years, have benefited or harmed your firm?" The responses were reordered for the analysis, so that 1 means "mostly harmed" and 5 means "mostly benefited." ${ }^{14}$ Several

14. Our measure of "support for trade" is retrospective. Asking prospectively about support for future or hypothetical trade liberalizations is a 
142 / Superstar Exporters: Survey Evidence on Firms and Trade Policy lain Osgood et al.
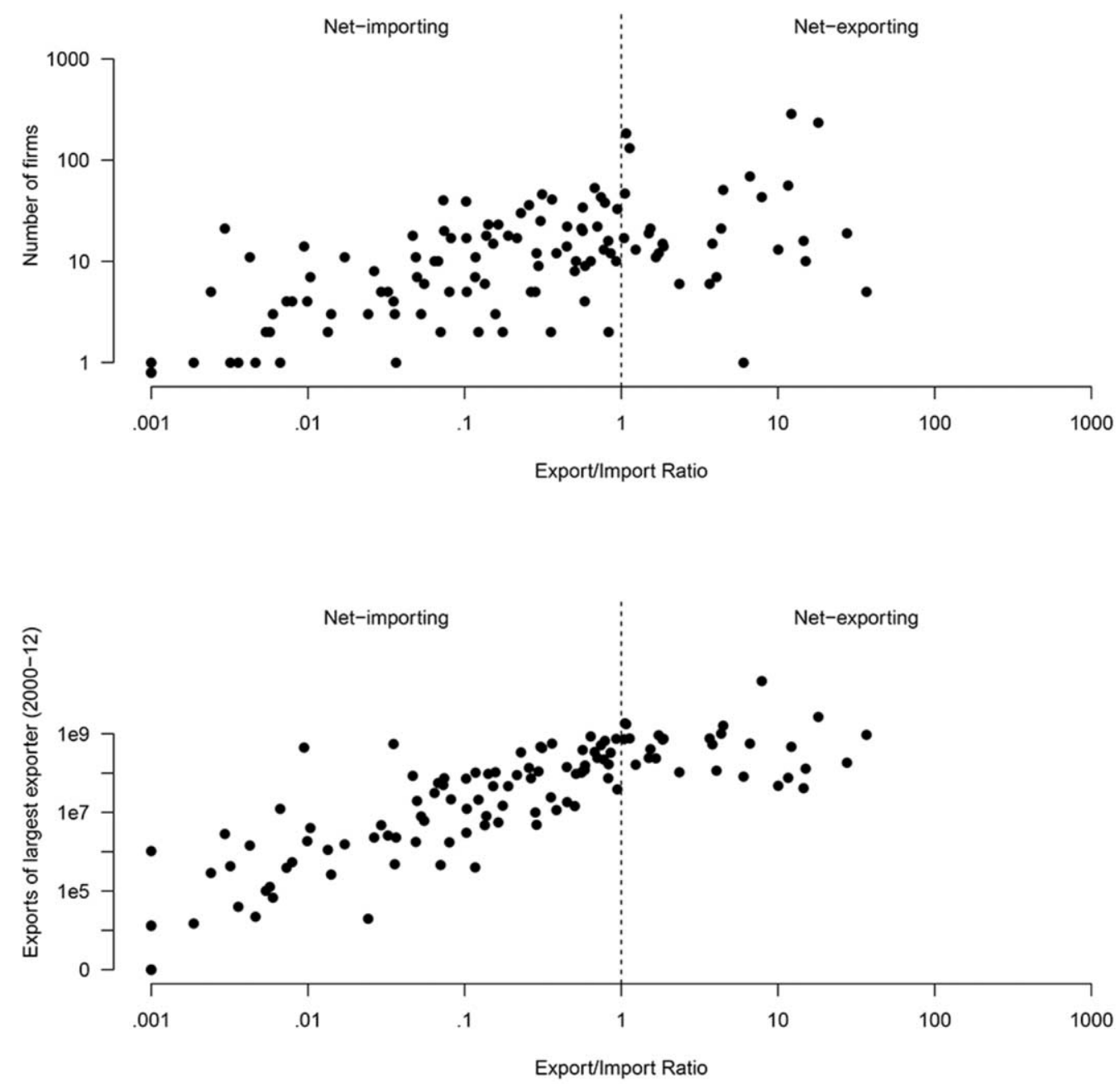

Figure 2. This figure illustrates the large number of exporting firms and the enormous sales accounted for by the largest exporters in net-importing industries. These industries would ordinarily be classified as "comparative disadvantage" in an empirical operationalization of the standard trade model, masking the considerable export success of particular firms within those industries. The firm-level data use the distribution of firms in 2012. $N=2,484$. The 2012 import data is taken from World Bank's World Integrated Trade Solution (WITS) at the HS6 level and concorded to ISIC Rev. 3.1 industries (International Standard Industrial Classification of All Economic Activities; World Bank 2015).

predicted correlates of support for trade are examined, all of which were gathered independently from the survey responses. These include whether a firm exported from 2000 to 2012 (Exporter [Procomer])), its average annual exports during the years the firm exported (In Annual exports), and the number of markets served by the firm (ln Number of markets).

These models (and those in subsequent tables) also include additional control variables. Most important among these are the proxies for industry-wide comparative advan-

valid alternative approach, but we suspected that answers to this question might be fuzzier because of the potential unknown effects of trade liberalization and concomitant policy changes. We refer throughout to expressions of "support" for trade liberalization as a convenient shorthand for what is actually a retrospective evaluation. tage, both of which are measured in a trichotomous manner with firms from the most competitive industries and firms with more "neutral" industries considered relative to a baseline of firms from the least competitive industries. These measures operationalize the Ricardo-Viner prediction that preferences are determined by the industry's comparative advantage, and they are based on Costa Rican trade data.

The first main proxy for comparative advantage uses the export sales relative to import sales of the firm's industry and breaks the industries up into terciles. The top tercile is called Comparative advantage; and the middle tercile is Neutral comparative advantage, although we stress that this outcomebased measure is only a proxy. This approach is commonly employed in the trade politics literature, but it raises concerns about potentially large correlations between the export sales of our respondents and industry-wide comparative 


\begin{tabular}{|c|c|c|c|c|c|c|}
\hline Outcome & Mean & Median & Min & Max & SD & Table \\
\hline \multicolumn{7}{|l|}{ Attitudes toward trade: } \\
\hline Benefits from reciprocal liberalization & 3.42 & 3 & 1 & 5 & 1.25 & 2 \\
\hline Import competition & 2.48 & 3 & 1 & 4 & 1.06 & 3 \\
\hline Export opportunities & 2.48 & 2 & 1 & 4 & 1.16 & 3 \\
\hline \multicolumn{7}{|l|}{ Intensity of interest and activity: } \\
\hline Trade policy important? & 3.79 & 4 & 1 & 5 & 1.11 & 4 \\
\hline Seek trade information & 3.23 & 3 & 1 & 5 & 1.14 & 4 \\
\hline Political contact & .36 & 0 & 0 & 1 & .48 & 4 \\
\hline Political contact about trade & .27 & 0 & 0 & 1 & .45 & 4 \\
\hline \multicolumn{7}{|l|}{ Firm-level explanatory variables: } \\
\hline Exporter & .83 & 1 & 0 & 1 & .37 & 2,3 \\
\hline ln Annual exports & 10.74 & 11.87 & 0 & 18.70 & 5.24 & All \\
\hline ln Number of markets & 1.90 & 2.08 & 0 & 4.51 & 1.20 & All \\
\hline Substitutability & 2.99 & 3 & 1 & 4 & .90 & All \\
\hline Foreign production & .28 & 0 & 0 & 1 & .45 & All \\
\hline Importer & .77 & 1 & 0 & 1 & .43 & All \\
\hline \multicolumn{7}{|c|}{$\begin{array}{l}\text { Industry-level explanatory variables (all factoral } \\
\text { with baseline omitted): }\end{array}$} \\
\hline Neutral comparative advantage & .32 & 0 & 0 & 1 & .47 & All \\
\hline Comparative advantage & .34 & 0 & 0 & 1 & .47 & All \\
\hline Neutral RCA & .34 & 0 & 0 & 1 & .47 & All \\
\hline Positive RCA & .34 & 0 & 0 & 1 & .48 & All \\
\hline Moderately differentiated & .32 & 0 & 0 & 1 & .47 & All \\
\hline Differentiated & .41 & 0 & 0 & 1 & .49 & All \\
\hline
\end{tabular}

Note. This table presents summary statistics for each of the seven outcome variables examined below, along with the table where the variable is examined as an outcome. Explanatory variables are listed on the lower half of the table. For all variables the range of outcomes across all respondents is presented; summary statistics are averaged across all imputed data sets. Industries that account for a relatively high proportion of Costa Rica's import sales, relative to the world's, are presumed to be less competitive. This variable is called Neutral RCA and Positive RCA.

advantage. Such concerns are unfounded, in principle, because only a minority of respondents control most export sales and firm heterogeneity is significant. They are also not present in practice: our measures of export participation and intensity are only weakly correlated, if at all, with our proxy for industry-wide comparative advantage among our respondents. ${ }^{15}$ Nonetheless, to avoid concerns about doublecounting export sales, we use a version of Balassa's (1965) revealed comparative advantage based on country-level import sales only. Industries that account for a relatively high proportion of Costa Rica's import sales, relative to the world's, are presumed to be less competitive. This variable is called Neutral RCA and Positive RCA.

15. The Spearman correlation between ln Annual exports and our ordinal measure proxy for comparatve advantage is .108; the correlations with Exporter (Procomer) and $\ln$ Number of markets are -.194 and -.023 , respectively. These correlations are similarly weak for the alternative proxy introduced below.
In addition to these main variables, we include several other controls. Product differentiation is operationalized as a trichotomous variable, where we include moderately differentiated (Moderately differentiated) and highly differentiated (Differentiated) dummies with an excluded category for homogeneous (i.e., relatively undifferentiated) products. ${ }^{16}$ We also control for three other firm-level variables: the respondents' evaluations of the ease with which their products might be replaced by a competitors' (Substitutability), whether the firm has foreign production facilities (Foreign production), and whether the firm reported importing intermediate goods from abroad (Importer). ${ }^{17}$ Measurement details for these variables are contained in appendix B.

16. This discretization follows the original measure developed in Rauch (1999), which is reflected in a clear multimodal structure when this measure is concorded into the ISIC classification scheme.

17. The Substitutability variable is based on a 4-point Likert scale question that asked, "When people buy your product or products, how 
144 / Superstar Exporters: Survey Evidence on Firms and Trade Policy lain Osgood et al.

Table 2. Benefits from Reciprocal Liberalization

(1)

$\begin{array}{lc}\text { Exporter (Procomer) } & .836^{* * *} \\ \text { ln Annual exports } & (.323) \\ \text { ln Number of markets } & \\ \text { Neutral comparative advantage } & .064 \\ & (.293) \\ \text { Comparative advantage } & .322 \\ & (.284)\end{array}$

Neutral RCA

Positive RCA

Moderately differentiated

Differentiated

Substitutability

Foreign production

Importer

$(.284)$

\begin{tabular}{cccccc} 
& .384 & & .350 & & .408 \\
& $(.300)$ & & $(.302)$ & & $(.298)$ \\
& -.050 & & -.092 & & -.025 \\
& $(.300)$ & & $(.304)$ & & $(.299)$ \\
$-.717^{\star \star}$ & $-.667^{\star \star}$ & $-.679^{\star \star}$ & $-.623^{\star \star}$ & $-.710^{\star \star}$ & $-.655^{\star \star}$ \\
$(.303)$ & $(.308)$ & $(.304)$ & $(.309)$ & $(.303)$ & $(.307)$ \\
-.468 & $-.550^{\star}$ & -.372 & -.441 & -.404 & -.485 \\
$(.311)$ & $(.308)$ & $(.319)$ & $(.319)$ & $(.317)$ & $(.315)$ \\
$-.262^{\star}$ & $-.257^{\star}$ & $-.270^{\star \star}$ & $-.267^{\star}$ & $-.269^{\star \star}$ & $-.259^{\star}$ \\
$(.136)$ & $(.138)$ & $(.137)$ & $(.138)$ & $(.137)$ & $(.138)$ \\
.187 & .191 & .121 & .131 & .099 & .116 \\
$(.269)$ & $(.269)$ & $(.273)$ & $(.273)$ & $(.273)$ & $(.272)$ \\
$-.615^{\star \star}$ & $-.717^{\star \star}$ & $-.647^{\star \star}$ & $-.749^{\star \star}$ & $-.568^{\star}$ & $-.661^{\star \star}$ \\
$(.309)$ & $(.307)$ & $(.313)$ & $(.313)$ & $(.312)$ & $(.308)$ \\
\hline
\end{tabular}

Note. $N=268$. Ordinal logistic regression of self-reported benefits from reciprocal trade liberalization on various objective measures of export ability. In all models, the measure of export ability is a significant predictor of support for trade liberalization, even conditional on comparative advantage of the respondent's industry. Industries that account for a relatively high proportion of Costa Rica's import sales, relative to the world's, are presumed to be less competitive. These variables are called Neutral RCA and Positive RCA. Standard errors are in parentheses.

${ }^{*} p<.10$.

${ }^{* *} p<.05$.

${ }^{* * *} p<.01$.

The models relating our objective correlates of export capacity to support for trade strongly suggest that an individual firm's export ability is more important than the orientation of their industry toward the international economy. Export ability, at both the extensive and intensive margin, is strongly associated with support for the belief that recipro-

easy is it to find a product made by another company that is similar to yours?" While this variable is clearly conceptually related to the product differentiation measure, the overlap is not perfect between the two. (The Spearman correlation between the two measures is .17). This is so for two reasons. First, there may be intra-industry variation in the extent to which firms consider their product substitutable, which is of course not picked up by our Differentiation variable, which is industry-level. Second, the Substitutability variable may be picking up an even higher level of differentiation that goes beyond the Rauch measure. Our results are entirely robust to the exclusion of this variable. cal trade liberalization benefits the respondent's firm. This is true even conditional on our proxies for industry-wide comparative advantage, which, although generally signed in the direction that the standard trade model might predict, are not statistically significant in any specification. ${ }^{18}$

We supplement this first main finding with several selfreported measures of competitiveness. First, we regress support for trade liberalization on the in-survey measure of whether a firm exports or not (Exporter (reported)). We find

18. We also considered an alternative proxy for comparative advantage commonly used in the literature, the log ratio of exports to imports. We used versions of this measure for our firms' main industries only and for all of their 4-digit ISIC industries. In all instances, this comparative advantage measure was not statistically significant, and the effects of export performance on support for liberalization remained sizable and significant. 
a positive correlation between exporting and support for trade, although not one that is significant at the $10 \%$ level. We also consider two subjective measures of firm ability: self-diagnosed "efficiency" (Efficiency) and "productivity" (Productivity) relative to other firms in the same industry. The productivity measure is positively correlated with support for trade and significant at the $10 \%$ level, while the efficiency measure has a positive coefficient that is not significant. These results are contained in table $\mathrm{C} 1$ of the appendix.

A further question that arises when considering firm heterogeneity in export success is whether other firm-level characteristics that might be correlated with export behavior are driving our results. Having foreign production facilities appears to have no effect on support or opposition to trade. We also include a dummy variable for whether the firm reports being a direct importer. ${ }^{19}$ We generally find that self-reported importers express less enthusiasm about trade liberalization. This puzzling correlation may be attributed to question wording (our survey asked about "reductions of international trade barriers in your industry"), but it is not the result of the high correlation between importing and export status, which is relatively modest, as described above.

In order to check that our main findings are not being solely driven by question wording or other features of our outcome variable, we consider two alternative measures of support for trade liberalization contained within our survey. The first of these is a 7-point Likert scale question about whether trade liberalization via the WTO process has "generally benefited" or "generally harmed" the respondent's firm. ${ }^{20}$ The second measure averages respondents' answers to a 5point Likert scale survey question about support or opposition to further liberalization with each of eight trade partners, including China and the United States. ${ }^{21}$ These models are reported as online appendix tables $\mathrm{C} 2$ and $\mathrm{C} 3$, respectively. Employing the WTO question, all of our firm-level variables are positive predictors of support for trade even conditional on industry-wide comparative advantage. Five of seven of

19. Our measure of multinational status was based on a survey question ("Does your firm own production facilities in other countries besides Costa Rica?"). Our measure of importing was based on a survey question ("Does your firm import?"). This measure is positively correlated with exporting ( $\rho=$ .174) but not highly collinear.

20. The question asked: "Now consider broad multilateral trade agreements, for example, those negotiated through the World Trade Organization. Do these types of agreements generally benefit or harm your firm?"

21. "Would your firm's management support or oppose efforts to further reduce tariff and non-tariff barriers to trade between Costa Rica and the following countries?" The countries (or regions) listed for separate answer were the United States, Mexico, Central America, Japan, Brazil, China, Panama, and the European Union. Responses were averaged across these countries. these are statistically significant at the $10 \%$ level, and in particular, our measures of export intensity are significant. Employing the averaged support for further liberalization with various countries, all of our firm-level predictors are again signed correctly, but only four of seven are statistically significant at the $10 \%$ level (these are our measures of export intensity from the Procomer data).

Finally, at the suggestion of a reader, we examined alternative versions of the main explanatory variables, ln Annual exports and ln Number of markets, which isolate the intra-industry component of variation in export success. To do so, we ranked all Procomer firms in a given 4-digit ISIC industry based on their annual exports and numbers of markets served. These rankings were normalized to fall on a scale of 0 to 1 (with 1 representing the most export sales or markets in a given industry) and then matched these measures to our respondents. Nonexporters were given a rating of 0 . We found extremely similar results across all three of our survey-based measures of support for trade liberalization, and we include these results in appendix table $\mathrm{C}$. All of the coefficients on the rank-based measures of export ability were significant at the $5 \%$ level.

\section{What impacts of trade liberalization do firms consider important?}

The second main set of results for this section examines the importance of various dimensions of trade policy to firms: competition from foreign producers (Import competition) and opportunities to directly export abroad (Export opportunities), primarily. ${ }^{22}$ There are two main purposes of these models: first, to demonstrate that firm-level, over and above industryor factoral-level predictors, take precedence in determining the salience of facets of trade policy; second, to show that firms' evaluations of trade policy's impacts do not fit either of the standard approaches in the literature but are consistent with the emphasis on intra-industry trade in modern approaches to trade policy.

First, consider the two models that examine firms' evaluation of the importance of import competition when considering trade liberalization, reported in table 3 in columns 1 and 2. The extent of industry comparative disadvantage (Comparative advantage), which a Ricardo-Viner approach

22. This question asked "In evaluating the impact of reductions in international trade barriers on your firm's profits, how important are the following considerations? Increased competition from foreign producers; Increased opportunities for exports to foreign markets; Increased opportunities for sourcing of inputs from abroad; Increased opportunities for exports by firms my company supplies; Changes in wages/salaries for skilled workers; Changes in wages for unskilled workers?" 
146 / Superstar Exporters: Survey Evidence on Firms and Trade Policy lain Osgood et al.

Table 3. Ordinal Logistic Regression of Various Dimensions of Liberalization on Selected Predictors

\begin{tabular}{|c|c|c|c|c|c|}
\hline & \multicolumn{2}{|c|}{ Import Competition } & \multicolumn{3}{|c|}{ Export Opportunities } \\
\hline & $(1)$ & $(2)$ & (3) & $(4)$ & $(5)$ \\
\hline Exporter (Procomer) & $\begin{array}{c}-.108 \\
(.327)\end{array}$ & & $\begin{array}{l}.750^{* *} \\
(.359)\end{array}$ & & \\
\hline ln Annual exports & & & & $\begin{array}{l}.065^{\star *} \\
(.026)\end{array}$ & \\
\hline ln Number of markets & & & & & $\begin{array}{l}.255^{\star *} \\
(.106)\end{array}$ \\
\hline Neutral comparative advantage & $\begin{array}{c}-.137 \\
(.285)\end{array}$ & & $\begin{array}{c}.192 \\
(.290)\end{array}$ & $\begin{array}{l}.167 \\
(.289)\end{array}$ & $\begin{array}{c}.158 \\
(.290)\end{array}$ \\
\hline Comparative advantage & $\begin{array}{r}-.059 \\
(.289)\end{array}$ & & $\begin{array}{c}.306 \\
(.286)\end{array}$ & $\begin{array}{c}.247 \\
(.285)\end{array}$ & $\begin{array}{c}.254 \\
(.286)\end{array}$ \\
\hline Moderately differentiated & $\begin{array}{r}-.069 \\
(.300)\end{array}$ & & $\begin{array}{c}-.656^{\star \star} \\
(.298)\end{array}$ & $\begin{array}{c}-.615^{\star *} \\
(.300)\end{array}$ & $\begin{array}{c}-.642^{\star *} \\
(.299)\end{array}$ \\
\hline Differentiated & $\begin{array}{c}.385 \\
(.317)\end{array}$ & & $\begin{array}{c}-.886^{* * *} \\
(.313)\end{array}$ & $\begin{array}{c}-.798^{\star *} \\
(.321)\end{array}$ & $\begin{array}{c}-.805^{\star *} \\
(.319)\end{array}$ \\
\hline Substitutability & $\begin{array}{l}.468^{* * *} \\
(.135)\end{array}$ & & $\begin{array}{c}-.120 \\
(.136)\end{array}$ & $\begin{array}{c}-.129 \\
(.136)\end{array}$ & $\begin{array}{c}-.126 \\
(.135)\end{array}$ \\
\hline Foreign production & $\begin{array}{r}-.330 \\
(.255)\end{array}$ & & $\begin{array}{c}-.347 \\
(.270)\end{array}$ & $\begin{array}{r}-.415 \\
(.271)\end{array}$ & $\begin{array}{c}-.426 \\
(.271)\end{array}$ \\
\hline Importer & $\begin{array}{c}-.187 \\
(.295)\end{array}$ & & $\begin{array}{c}-.776^{\star *} \\
(.310)\end{array}$ & $\begin{array}{c}-.824^{\star * *} \\
(.315)\end{array}$ & $\begin{array}{c}-.747^{\star *} \\
(.307)\end{array}$ \\
\hline Export opportunities & & $\begin{array}{l}.207^{\star *} \\
(.099)\end{array}$ & & & \\
\hline
\end{tabular}

\footnotetext{
Note. $N=268$. Respondents answered whether each dimension, import competition or indirect export opportunities, for example, are important considerations in assessing proposed trade liberalizations. Standard errors are in parentheses.

says would be the most important predictor of import competition being a serious issue, has only modest and statistically insignificant effects. Firms in net-importing industries are not significantly more concerned about import competition than those in other industries. One explanation for this may lie in the strongly positive impact of firm-level evaluations of product substitutability on concerns about import competition. Firms that feel that their products are easy to replace with varieties made by competitors are extremely worried about the impact of import competition; firms that feel that their products are more difficult to find substitutes for are much less concerned. Thus, precisely the same analytic factor that gives rise to intra-industry trade also buffers firms from the greatest depredations of import competition, as argued in Krugman (1981).

The key role of intra-industry trade is also emphasized in model 2. It shows that those firms that are concerned about import competition associated with trade liberalization are the same firms that are concerned about export opportunities associated with trade liberalization (Export opportunities). This is entirely at odds with a Ricardo-Viner or StolperSamuelson view of the world, but it fits nicely into approaches emphasizing the importance of intra-industry trade.

The respondents' identification of export opportunities (Export opportunities, the dependent variable in models 3, 4, and 5) as an important consideration in evaluating trade liberalization serve to illustrate the other key piece of the "new, new" trade politics: firm heterogeneity. Industry comparative advantage is only intermittently a significant predictor of considering export opportunities an important feature of trade liberalization. But, as in table 2, both export status (Exporter) and intensity (ln Annual exports and ln Number markets) have large positive effects on seeing export opportunities as important, even conditional on the comparative advantage of the industry. This suggests something important: the broad price movements emphasized in stan- 
dard trade models may play a role, but the actual export status of an individual firm is just as, if not more, important.

Finally, it is worth noting that firms generally rated changes in wage rates, whether among skilled or unskilled workers, as the least important determinants of their trade attitudes. Among responding firms, $73 \%$ and $78 \%$ of respondents reported that changes in skilled and unskilled workers wages were "not important" or only "somewhat important" in evaluating trade policy changes. Only $49 \%$ and $51 \%$, respectively, felt the same about changes in import competition or export opportunities, and a far greater proportion of these groups felt that these changes were "very important." This suggests that the changes in wages emphasized in general equilibrium models of trade, such as certain versions of the HeckscherOhlin model and in Melitz (2003), are not of central concern to firms. Direct competition and export opportunities, as in Melitz and Ottaviano (2008), are.

\section{Firm interest and engagement with trade policy}

This subsection builds on the findings in the previous sections by considering the level of interest and active engagement with trade policy among firms. Our existing trade theories suggest that the importance attached to trade policy by producers within a single industry should generally be the same: all producers of the same good will face the same changes in goods and factor prices and so all will face proportional gains or losses resulting from trade liberalization.

The new, new trade theory emphasizes that firms differ sharply in their ability to access foreign markets and that the largest exporters see outsized gains from trade liberalization. The rest of firms - small- to medium-sized exporters, and nonexporters - see modest or no increases in sales from liberalization, and they face greater competition at home. These distributive consequences therefore suggest preference intensity about trade policy should be most concentrated in the hands of the largest exporters. These "happy few" who control almost all international trade are also expected to be the most engaged in trade politics, owing to their strong preferences and greater material resources (Mayer and Ottaviano 2008). The evidence provided below is strongly in support of this view. These models are reported in table 4 .

Each model considers the responses among exporters only to a series of questions about the interest and political activities of firms surrounding trade politics. Firms were asked "In general, do you think that decisions by the government of Costa Rica on international trade policy have big or small consequences for your firm?" with potential answers on a 5-point Likert scale from "Very small" to "Very big." Firms were also asked "With what frequency does the management of your firm seek information on and discuss global and bilateral trade negotiations involving Costa Rica, such as the WTO Doha Round or bilateral negotiations between Costa Rica and the European Union on a trade agreement?" with answers spanning "Never" to "Very often" on a 5 -point scale. The answers to these questions are examined in models 1 and 2 and in models 3 and 4, respectively, of table 4.

We also asked firms about the extent of their lobbying activities, both in general and on trade issues specifically, although we phrased the questions in terms of "contacting" the Office of the President, COMEX, or a member of the Asamblea Legislativa about some political issue or problem. ${ }^{23}$ Recall that these are the three main political institutions with authority on making trade policy. The results of these models are presented in models 5 and 6 and in models 7 and 8 of table 4 . The core explanatory variables relate to the intensity of export activities: the average annual exports for all years with positive exports (ln Annual exports) and the number of markets served by the firm (ln Number of markets).

In all cases, these variables are positively correlated with each of the four outcomes (and in six of eight cases these relationships are statistically significant). In sharp contrast, separate unreported models that consider the impact of export status only generally produce positive but insignificant relationships. It is the extent of exporting that is most important in determining interest of firms rather than the mere fact of exporting on its own.

As with the models of preferences, we also examined a rank-based measure of export performance that compares firms within-industry only, and so we eliminated from consideration inter-industry differences in size and competitiveness. These results are provided in appendix table C5. We found virtually identical patterns of sign and statistical significance, with the sole exception of the effect of the rankbased measure of average annual exports on seeking information about trade, which was not significant.

These results are consistent with several of the stylized facts that have emerged in the literature on heterogeneity in export performance. Exporting is highly concentrated in the hands of a small group of firms, and only the most successful

23. The exact question was "Some firms are quite active in politics, while others tend not to take an active part. We would like to know if, during the last three to four years, your firm has contacted a member of Congress, COMEX, or the Presidency about some political issue or problem?" The responses were Yes, No, and Don't know. For firms that answered Yes to this question, we asked a follow-up: "You mentioned that your firm has contacted members of Congress, COMEX, or the Presidency about a political issue. Did any of these issues concern international trade or outsourcing?" which had Yes or No responses. 
148 / Superstar Exporters: Survey Evidence on Firms and Trade Policy lain Osgood et al.

Table 4. Various Measures of Political Interests and Lobbying Surrounding Trade Issues

\begin{tabular}{|c|c|c|c|c|c|c|c|c|}
\hline & \multicolumn{2}{|c|}{ Trade Important? } & \multicolumn{2}{|c|}{ Seek Trade Information } & \multicolumn{2}{|c|}{ Contacted Policy Makers } & \multicolumn{2}{|c|}{ Contacted about Trade } \\
\hline & $(1)$ & $(2)$ & (3) & (4) & (5) & (6) & (7) & (8) \\
\hline ln Annual exports & $\begin{array}{c}.138^{\star} \\
(.073)\end{array}$ & & $\begin{array}{l}.143^{\star \star} \\
(.070)\end{array}$ & & $\begin{array}{l}.263^{\star * *} \\
(.083)\end{array}$ & & $\begin{array}{l}.207^{\star *} \\
(.087)\end{array}$ & \\
\hline ln Number of markets & & $\begin{array}{c}.035 \\
(.151)\end{array}$ & & $\begin{array}{c}.154 \\
(.147)\end{array}$ & & $\begin{array}{l}.558^{\star * *} \\
(.197)\end{array}$ & & $\begin{array}{l}.564^{\star * *} \\
(.202)\end{array}$ \\
\hline Neutral comparative advantage & $\begin{array}{c}.186 \\
(.349)\end{array}$ & $\begin{array}{c}.250 \\
(.343)\end{array}$ & $\begin{array}{c}.028 \\
(.345)\end{array}$ & $\begin{array}{c}.088 \\
(.343)\end{array}$ & $\begin{array}{r}-.110 \\
(.436)\end{array}$ & $\begin{array}{r}-.035 \\
(.436)\end{array}$ & $\begin{array}{c}-.508 \\
(.494)\end{array}$ & $\begin{array}{c}-.478 \\
(.501)\end{array}$ \\
\hline Comparative advantage & $\begin{array}{c}.750^{\star} \\
(.381)\end{array}$ & $\begin{array}{l}.871^{\star *} \\
(.368)\end{array}$ & $\begin{array}{c}.143 \\
(.347)\end{array}$ & $\begin{array}{c}.290 \\
(.339)\end{array}$ & $\begin{array}{c}.648 \\
(.397)\end{array}$ & $\begin{array}{l}.840^{\star *} \\
(.391)\end{array}$ & $\begin{array}{c}.366 \\
(.406)\end{array}$ & $\begin{array}{c}.514 \\
(.401)\end{array}$ \\
\hline Moderately differentiated & $\begin{array}{c}-.834^{\star *} \\
(.340)\end{array}$ & $\begin{array}{c}-.918^{\star * *} \\
(.339)\end{array}$ & $\begin{array}{r}-.326 \\
(.341)\end{array}$ & $\begin{array}{r}-.433 \\
(.339)\end{array}$ & $\begin{array}{r}-.502 \\
(.399)\end{array}$ & $\begin{array}{r}-.639 \\
(.390)\end{array}$ & $\begin{array}{r}-.511 \\
(.455)\end{array}$ & $\begin{array}{r}-.624 \\
(.455)\end{array}$ \\
\hline Differentiated & $\begin{array}{c}-.462 \\
(.379)\end{array}$ & $\begin{array}{r}-.695^{\star} \\
(.360)\end{array}$ & $\begin{array}{r}-.098 \\
(.372)\end{array}$ & $\begin{array}{c}-.270 \\
(.362)\end{array}$ & $\begin{array}{r}-.085 \\
(.454)\end{array}$ & $\begin{array}{r}-.290 \\
(.434)\end{array}$ & $\begin{array}{c}.177 \\
(.481)\end{array}$ & $\begin{array}{c}.084 \\
(.470)\end{array}$ \\
\hline Substitutability & $\begin{array}{c}.171 \\
(.152)\end{array}$ & $\begin{array}{l}.188 \\
(.152)\end{array}$ & $\begin{array}{c}.242 \\
(.152)\end{array}$ & $\begin{array}{c}.267^{\star} \\
(.152)\end{array}$ & $\begin{array}{c}.190 \\
(.196)\end{array}$ & $\begin{array}{c}.201 \\
(.194)\end{array}$ & $\begin{array}{c}.171 \\
(.195)\end{array}$ & $\begin{array}{c}.186 \\
(.195)\end{array}$ \\
\hline Foreign production & $\begin{array}{c}-.101 \\
(.308)\end{array}$ & $\begin{array}{c}.061 \\
(.298)\end{array}$ & $\begin{array}{c}.115 \\
(.316)\end{array}$ & $\begin{array}{c}.230 \\
(.309)\end{array}$ & $\begin{array}{c}-.140 \\
(.413)\end{array}$ & $\begin{array}{c}-.056 \\
(.404)\end{array}$ & $\begin{array}{c}-.301 \\
(.393)\end{array}$ & $\begin{array}{r}-.298 \\
(.389)\end{array}$ \\
\hline Importer & $\begin{array}{r}-.243 \\
(.387)\end{array}$ & $\begin{array}{r}-.133 \\
(.383)\end{array}$ & $\begin{array}{c}.422 \\
(.359)\end{array}$ & $\begin{array}{c}.530 \\
(.358)\end{array}$ & $\begin{array}{l}.977^{\star \star} \\
(.489)\end{array}$ & $\begin{array}{l}1.185^{\star \star} \\
(.491)\end{array}$ & $\begin{array}{c}.533 \\
(.492)\end{array}$ & $\begin{array}{c}.710 \\
(.498)\end{array}$ \\
\hline
\end{tabular}

Note. $N=223$. Issues examined include a belief that trade policy is impactful, seeking information about trade, and contact with the major policy-making institutions about political issues or problems, both generally and with specific reference to international trade. All models are estimated among exporters only-in general each of these outcomes was not strongly correlated with export status per se but are apparently strongly correlated with the intensity of export activity. Comparative advantage is positively, but not consistently, correlated with interst and activity around trade policy. Standard errors are in parentheses.

${ }^{*} p<.10$

${ }^{* *} p<.05$.

${ }^{* * *} p<.01$.

export in high volumes and to a large number of markets. We noted earlier that Costa Rica has pursued a steady course of neoliberal reforms and integration with global markets that have sparked considerable controversy. Our earlier results suggest that these reforms have received the enthusiastic support of Costa Rica's largest and most successful exporters, regardless of the overall orientation of their industry toward the global economy. Here we have shown that large firms dominate the politicking surrounding trade liberalization and globalization. At this point, we highlight the fit among these different strands of our paper: superstar exporters support trade and dominate trade politics, and they have succeeded in securing trade liberalization and global integration for Costa Rica.

\section{Summary}

This paper has three main empirical findings, each of which challenges the two dominant approaches to trade politics. Standard approaches predict that industries (or even all firms regardless of industry) will be united in support of or opposition to trade liberalization. We find that attitudes are best explained by firm-level characteristics regardless of industry features. Firms' evaluations of trade policy and patterns of preference intensity and political engagement also suggest patterns that existing approaches cannot explain. We summarize our main findings here.

First, we find robust and compelling evidence that the firm characteristics highlighted by the "new, new trade theory" are strong predictors of trade attitudes among firms. This correlation holds even conditional on industry-wide proxies for comparative advantage, which are in general not a statistically significant predictor of attitudes toward trade. This core finding is relatively insensitive to the proxy of firm productivity: objective measures of export activity and intensity, self-reported measures of firm sales, and subjective evaluations of firm productivity all suggest the same conclusions. Our results are also generally consistent across alternative mea- 
sures of support for trade and alternative measures of revealed comparative advantage at the industry level.

Our second main finding is that firms' evaluations of the key dimensions of trade liberalization are more consistent with "new, new trade" accounts than with standard approaches. Firm characteristics are much better predictors of concern about export opportunities and import competition than industry-level predictors. Concern about import competition and export opportunities are positively correlated, suggesting the importance of intra-industry trade flows. Finally, firms generally did not consider factor price changes to be key concerns when evaluating trade liberalization, as models of comparative advantage based on factor endowments might suggest.

Finally, we move the literature forward by examining the impact of firm size and export intensity on preference intensity and political activity. Among exporting firms, we find very strong links between export intensity and belief that trade policy is important and seeking information on trade policy. Similarly, we find strong correlations between export scale and engagement in policy activity, especially political activity that is trade related. We interpret this as evidence that the sharp skewness in export sales described in Bernard et al. (2014) and Mayer and Ottaviano (2008) feeds into political activity surrounding the making of trade policy.

To what larger story do these findings point? Beginning in the mid-1980s, Costa Rica - like many other developed and developing countries, both before and after-began a process of steadily increasing engagement with the global economy. While the causes of these changes are many, we highlight that this process coincided with changes in industrial structure and global trade. Concentration was increasing with the rise of superstar firms, even as product differentiation became a central organizing concern of corporations as well as the key explanation for the rise of intra-industry trade. We have shown here that these two forms of market power-size and monopolization of particular varieties - coincide strongly with both support for globalization and political power. Big exporting firms monopolizing their own varieties do not mind if trade liberalization increases imports in their industry as long as they gain access to new markets. These same firms also have structural advantages - greater financial resources and social capital — and face an ameliorated collective action problem due to their relatively small numbers and intense preferences. The likely opponents of globalization among firms are, in contrast, large in number, relatively weak in their preferences, and lacking in political power. We propose, then, that the rise of intra-industry trade - and of the superstar exporter divorced from the concerns of the weaker firms in his industry - has contributed to the steady erosion of trade barriers over the past several decades.

\section{CONCLUSION}

The study of preferences over trade over the past 20 years has two defining characteristics. The first of these is a focus on the preferences of individuals as voters either via public opinion surveys (e.g., Scheve and Slaughter 2001), voting patterns (e.g., Margalit 2011), or congressional roll call voting (Milner and Tingley 2011). In particular, the literature has come to focus on noninstrumental or psychological determinants of attitudes toward globalization (e.g., Mansfield and Mutz 2009). Second, to the extent that the literature has focused on instrumental theories of preferences, it has mainly revisited the long-running debate about asset specificity, industry, and factor ownership (Hiscox 2002; Rogowski 1989). This paper takes a different tack on both dimensions by focusing on firms and firm-level material factors. We find evidence for a rich politics of trade that highlights large differences among firms even within industries - a politics that merits much greater attention given the outsize role of firms in the process of making trade policy, especially relative to ordinary voters. We highlight in this conclusion some areas for further development.

As with any paper that uses data from a single country, future research ought to extend our conceptual framework and empirical strategy to other developing countries. We suspect that our results will travel, just as the results of previous work on developed countries appear to travel to the Costa Rican case we examine (see, e.g., Osgood 2017; Plouffe 2012). Ideally, new work in this area would combine elements of all of these papers: extensive firm-level data on operations and performance among both exporters and nonexporters, survey evidence on attitudes and behavior, and behavioral evidence on public position-taking, lobbying, and organization to corroborate survey findings "in the field."

A focus on firms also raises several natural areas for extending our theory. First, the study of firms in trade has identified other types of heterogeneity in the extent of global engagement, particularly in the multinationalization of production and in the extent of importing needed inputs. These ideas are examined in US data on firm position-taking in Osgood (2015), but there is a great deal of scope for further theoretical innovation in this area, as well as in the testing of ideas in surveys and in other country contexts. Second, the trade literature on firm heterogeneity has recently come to focus on the ways in which workers vary systematically across firms (e.g., Grossman, Helpman, and Kircher 2013; Helpman, Itskhoki, and Redding 2010). These papers have quite sophis- 
150 / Superstar Exporters: Survey Evidence on Firms and Trade Policy lain Osgood et al.

ticated arguments about worker attributes and sorting into firms based on ability, but the easiest extension of the "new, new trade" theory to workers may simply be to note that labor markets have frictions, and so any policy change that redistributes among firms also redistributes among workers, at least in the short term (see also Walter 2015). Surveys of workers matched to employer characteristics would therefore seem to be a natural next step. Third, while we have documented above the implications of firm heterogeneity for both attitudes and lobbying, much work remains to be done in understanding the implications of firm heterogeneity for the process and outcomes of trade politics. In part, this will mean understanding how changes in patterns of redistribution affect the incentives of policy demanders and suppliers, but it will also mean considering the interactions between interests and political institutions, which we see as fertile ground for future research.

What factors determine firms' preferences over trade policy? We find evidence that firm attributes - not features of their industries or factors of production - are the primary determinants of firms' attitudes toward trade. These findings suggest that it is time to move past earlier theories of trade politics-import-competing versus export-competing industries - and engage with models of trade politics built on the actual patterns of contemporary international trade, where intra-industry trade and firm heterogeneity in export performance are the norm. A close examination of firms' political attitudes and activities also suggests that organizing for trade politics may be more difficult than even theories of collective action had predicted and that the outsized influence of the global economy's winners is especially apparent in the politics of global economic policy.

\section{ACKNOWLEDGMENTS}

We gratefully acknowledge feedback from J. Lawrence Broz, Jeffry Frieden, Margaret Peters, Peter Rosendorff, and the participants in the 2015 annual conference of the International Political Economy Society. We also wish to thank Victor Umaña, Ronald Arce, and the team at INCAE.

\section{REFERENCES}

AAACP (Americas' Accountability Anti-Corruption Project). 2004. "Political-Party Finance in Argentina, Chile, Costa Rica and Mexico: Lessons for Latin America." Working paper, USAID.

Alt, James E., Jeffry Frieden, Michael J. Gilligan, Dani Rodrik, and Ronald Rogowski. 1996. "The Political Economy of International Trade Enduring: Puzzles and an Agenda for Inquiry." Comparative Political Studies 29 (6): 689-717.

Alt, James E., and Michael Gilligan. 1994. "The Political Economy of Trading States: Factor Specificity, Collective Action Problems, and Domestic Political Institutions." Journal of Political Philosophy 2 (2): 165-92.
Antras, Pol, and Elhanan Helpman. 2004. "Global Sourcing." Journal of Political Economy 112 (3): 552-80.

Aw, Bee Yan, Sukkyun Chung, and Mark Roberts. 2000. "Productivity and Turnover in the Export Market: Micro-Level Evidence from the Republic of Korea and Taiwan (China)." World Bank Economic Review 14 (1): 65-90.

Balassa, Bela. 1965. "Trade Liberalisation and 'Revealed' Comparative Advantage." Manchester School 33 (2): 99-123.

Bennett, Robert. 1998. "Business Associations and Their Potential Contribution to the Competitiveness of SMEs." Entrepreneurship and Regional Development 10 (3): 243-60.

Bennett, Robert, and Paul Robson. 1999. "The Use of External Business Advice by SMEs in Britain." Entrepreneurship and Regional Development 11 (2): 155-80.

Bernard, Andrew B., Jonathan Eaton, J. Bradford Jensen, and Samuel Kortum. 2003. "Plants and Productivity in International Trade." American Economic Review 93 (4): 1268-90.

Bernard, Andrew B., and J. Bradford Jensen. 1995. "Exporters, Jobs, and Wages in US Manufacturing: 1976-87." Brookings Papers on Economic Activity: Microeconomics 1995:67-112.

Bernard, Andrew B., and J. Bradford Jensen. 2004. "Why Some Firms Export." Review of Economics and Statistics 8 (2): 561-69.

Bernard, Andrew B., J. Bradford Jensen, Stephen J. Redding, and Peter K. Schott. 2007. "Firms in International Trade." Journal of Economic Perspectives 21 (3): 105-30.

Bernard, Andrew B., J. Bradford Jensen, and Peter K. Schott. 2009. "Importers, Exporters and Multinationals: A Portrait of Firms in the US That Trade Goods." In Timothy Dunne, J. Bradford Jensen, and Mark J. Roberts, eds., Producer Dynamics: New Evidence from Micro Data. Chicago: University of Chicago Press, 513-52.

Bernard, Andrew B., Ilke Van Beveren. and Hylke Vandenbussche. 2014. "Multi-Product Exporters and the Margins of Trade." Japanese Economic Review 65 (2): 142-57.

Berthou, Antoine, and Vincent Vicard. 2015. “Firms' Export Dynamics: Experience versus Size.” World Economy 38 (7): 1130-58.

Brülhart, Marius. 2009. “An Account of Global Intra-industry Trade, 19622006.” World Economy 32 (3): 401-59.

Busch, Marc L., and Eric Reinhardt. 2000. "Geography, International Trade, and Political Mobilization in U.S. Industries." American Journal of Political Science 44 (4): 720-32.

Büthe, Tim, and Walter Mattli. 2011. The New Global Rulers: The Privatization of Regulation in the World Economy. Princeton, NJ: Princeton University Press.

Casas-Zamora, Kevin, and Daniel Zovato. 2015. "The Cost of Democracy: Campaign Finance Regulation in Latin America." Policy brief, Latin America Initiative, Brookings Institution.

Cordero, Jose, and Eva Paus. 2008. "Foreign Investment and Economic Development in Costa Rica: The Unrealized Potential." Discussion paper no. 13, Working Group on Development and Environment in the Americas.

Das, Sanghamitra, Mark J. Roberts, and James R. Tybout. 2007. "Market Entry Costs, Producer Heterogeneity, and Export Dynamics." Econometrica 75 (3): 837-73.

Dixit, Avinsih K., and Joseph E. Stiglitz. 1977. "Monopolistic Competition and Optimum Product Diversity." American Economic Review 67 (3): 297-308.

Eaton, Jonathan, Marcela Eslava, Maurice Kugler, and James Tybout. 2007. "Export Dynamics in Colombia: Firm-Level Evidence." Working paper no. 13531, National Bureau of Economic Research, Cambridge, MA.

Echandi, Robert. 1997. "The Uruguay Round Agreements: Constitutional and Legal Aspects of their Implementation in Costa Rica." In John H. 
Jackson and Alan Sykes, eds., Implementing the Uruguay Round. Oxford: Oxford University Press, 399-440.

Freund, Caroline L., and Martha Denisse Pierola. 2012. "Export Superstars." Policy Research Working paper no. 6222, World Bank, Washington, DC.

Gawande, Kishore, and Usree Bandyopadhyay. 2000. "Is Protection for Sale? Evidence on the Grossman-Helpman Theory of Endogenous Protection." Review of Economics and Statistics 82 (1): 139-52.

Girma, Sourafel, and Holger Görg. 2007. "Multinational's Productivity Advantage: Scale or Technology?” Economic Inquiry 45 (2): 350-62.

Girma, Sourafel, David Greenaway, and Richard Kneller. 2003. "Export Market Exit and Performance Dynamics: A Causality Analysis of Matched Firms." Economics Letters 80 (2): 181-87.

Greenaway, David, and Richard Kneller. 2007. "Firm Heterogeneity, Exporting and Foreign Direct Investment.” Economic Journal 117 (517): F134-F161.

Grossman, Gene M., Elhanan Helpman, and Philipp Kircher. 2013. "Matching and Sorting in a Global Economy." Working paper no. 19153, National Bureau of Economic Research, Cambridge, MA.

Grubel, Herbert G., and Peter J. Lloyd. 1971. "The Empirical Measurement of Intra-industry Trade.” Economic Record 47 (120): 494-517.

Grubel, Herbert G., and Peter J. Lloyd. 1975. Intra-industry Trade: The Theory and Measurement of International Trade in Differentiated Products. London: Macmillan.

Hathaway, Oona A. 1998. "Positive Feedback: The Impact of Trade Liberalization on Industry Demands for Protection." International Organization 52 (3): 575-612.

Hausmann, Ricardo, César A. Hidalgo, Sebastián Bustos, Michele Coscia, Alexander Simoes, and Muhammed A. Yildirim. 2014. The Atlas of Economic Complexity: Mapping Paths to Prosperity. Cambridge, MA: MIT Press.

Helpman, Elhanan. 1981. "International Trade in the Presence of Product Differentiation, Economies of Scale and Monopolistic Competition: A Chamberlin-Heckscher-Ohlin Approach." Journal of International Economics 11 (3): 305-40.

Helpman, Elhanan, Oleg Itskhoki, and Stephen Redding. 2010. "Unequal Effects of Trade on Workers with Different Abilities." Journal of the European Economic Association 8 (2-3): 421-33.

Helpman, Elhanan, and Paul Krugman. 1985. Market Structure and Foreign Trade. Cambridge, MA: MIT Press.

Hicks, Raymond, Helen V. Milner, and Dustin Tingley. 2014. "Trade Policy, Economic Interests, and Party Politics in a Developing Country: The Political Economy of CAFTA-DR." International Studies Quarterly 58 (1): 106-17.

Hiscox, Michael. 2002. International Trade and Political Conflict: Commerce, Coalitions, and Mobility. Princeton, NJ: Princeton University Press.

Honaker, James, Gary King, and Matthew Blackwell. 2009. “AMELIA II: A Program for Missing Data.” http://gking.harvard.edu/amelia (accessed on March 11, 2016).

Huggins, Robert, and Andrew Johnston. 2010. "Knowledge Flow and Inter-firm Networks: The Influence of Network Resources, Spatial Proximity and Firm Size." Entrepreneurship and Regional Development 22 (5): 457-84.

Imai, Kosuke, Gary King, and Olivia Lau. 2008. "Toward a Common Framework for Statistical Analysis and Development." Journal of Computational Graphics and Statistics 17 (4): 1-22.

Kenyon, Tom, and Yotam Margalit. 2014. "Does Joining International Treaties Attract Foreign Investment? Experimental Firm-Level Evidence." Working paper, Columbia University.

Kim, In Song. 2014a. "Political Cleavages within Industry: Firm-Level Lobbying for Trade Liberalization. Massachusetts Institute of Technology." Working paper, Massachusetts Institute of Technology.
Kim, In Song. 2014b. "A Theory of Open Trade with Heterogeneous Firms." Working paper, Massachusetts Institute of Technology.

Krugman, Paul. 1980. "Scale Economies, Product Differentiation, and the Pattern of Trade." American Economic Review 70 (5): 950-59.

Krugman, Paul. 1981. "Intraindustry Specialization and the Gains from Trade.” Journal of Political Economy 89 (5): 959-73.

Kuno, Arata, and Megumi Naoi. 2015. "Framing Business Interests: How Campaigns Affect Firms' Positions on Preferential Trade Agreements.” Working paper, Kyorin University.

Lancaster, Kelvin. 1979. Variety, Equity, and Efficiency: Product Variety in an Industrial Society. New York: Columbia University Press.

Malesky, Edmund J., and Markus Taussig. 2009. "Where Is Credit Due? Legal Institutions, Connections, and the Efficiency of Bank Lending in Vietnam." Journal of Law, Economics, and Organization 25 (2): 53578.

Malmberg, Anders, Bo Malmberg, and Per Lundequist. 2000. "Agglomeration and Firm Performance: Economies of Scale, Localisation, and Urbanisation among Swedish Export Firms." Environment and Planning A 32 (2): 305-22.

Mansfield, Edward D., and Diana C. Mutz. 2009. "Support for Free Trade: Self-Interest, Sociotropic Politics, and Out-group Anxiety.” International Organization 63 (3): 425-57.

Margalit, Yotam. 2011. "Costly Jobs: Trade-Related Layoffs, Government Compensation, and Voting in US Elections." American Political Science Review 105 (1): 166-88.

Mayer, Thierry, and Gianmarco Ottaviano. 2008. "The Happy Few: The Internationalisation of European Firms." Intereconomics 43 (3): 13548.

Melitz, M. J. 2003. "The Impact of Trade on Intra-industry Reallocations and Aggregate Industry Productivity." Econometrica 71 (6): 1695-1725.

Melitz, Marc J., and Gianmarco I. P. Ottaviano. 2008. "Market Size, Trade, and Productivity." Review of Economic Studies 75 (1): 295-316.

Milner, Helen V. 1988. Resisting Protectionism: Global Industries and the Politics of International Trade. Princeton, NJ: Princeton University Press.

Milner, Helen V., and Dustin H. Tingley. 2011. "Who Supports Global Economic Engagement? The Sources of Preferences in American Foreign Economic Policy." International Organization 65 (1): 37-68.

Mosley, Layna. 2003. Global Capital and National Governments. Cambridge: Cambridge University Press.

Muûls, Mirabelle, and Mauro Pisu. 2009. "Imports and Exports at the Level of the Firm: Evidence from Belgium." World Economy 32 (5): 692-734.

Osgood, Iain. 2015. "Globalizing the Supply Chain: Intermediates, Global Production and Support for Trade." Working paper, University of Michigan

Osgood, Iain. 2016. "Differentiated Products, Divided Industries: Firm Preferences over Trade." Economics and Politics 28 (2): 161-80.

Osgood, Iain. 2017. "The Breakdown of Industrial Opposition to Trade: Firms, Product Variety and Reciprocal Liberalization." World Politics 69 (1) (forthcoming).

Paus, Eva. 2005. Foreign Investment, Development, and Globalization: Can Costa Rica Become Ireland? New York: Palgrave Macmillan.

Pavcnik, Nina. 2002. "Trade Liberalization, Exit, and Productivity Improvements: Evidence from Chilean Plants." Review of Economic Studies 69 (1): 245-76.

Plouffe, Michael. 2012. "The New Political Economy of Trade: Heterogeneous Firms and Politics." Unpublished paper, University College London.

Rauch, James E. 1999. "Networks versus Markets in International Trade." Journal of International Economics 48 (1): 7-35. 


\section{2 / Superstar Exporters: Survey Evidence on Firms and Trade Policy lain Osgood et al.}

Rodrik, Dani. 1995. "Political Economy of Trade Policy." In Gene Grossman and Kenneth Rogoff, eds., Handbook of International Economics, vol. 3. Amsterdam: Elsevier, 1457-94.

Rogowski, Ronald. 1989. Commerce and Coalitions: How Trade Affects Domestic Political Alignments. Princeton, NJ: Princeton University Press.

Rubin, Donald B. 2004. Multiple Imputation for Nonresponse in Surveys. New York: Wiley.

Samphantharak, Krislert, and Edmund J, Malesky. 2008. "Predictable Corruption and Firm Investment: Evidence from a Natural Experiment and Survey of Cambodian Entrepreneurs." Quarterly Journal of Political Science 3 (3): 227-67.

Scheve, Kenneth F., and Matthew J. Slaughter. 2001. "What Determines Individual Trade-Policy Preferences?" Journal of International Economics 54 (2): 267-92.

Singh, J. P. 2005. "Services Commitments: Case Studies from Belize and Costa Rica." In Peter Gallagher, Patrick Low, and Andrew Stoler, eds., Managing the Challenges of WTO Participation: Forty-Five Case Studies. Cambridge: Cambridge University Press, 78-94.

Tomiura, Eiichi. 2007. "Foreign Outsourcing, Exporting, and FDI: A Productivity Comparison at the Firm Level.” Journal of International Economics 72 (1): 113-27.
Tybout, J. R. 2003. "Plant- and Firm-Level Evidence on 'New' Trade Theories." In E. Kwan Choi and James Harrigan, eds., Handbook of International Trade. Hoboken, NJ: Wiley-Blackwell, 388-415.

UNCTAD. 2015. "World Investment Report 2015: Country Fact SheetCosta Rica." Presented at United Nations Conference on Trade and Development, Geneva.

Wagner, Joachim. 2007. "Exports and Productivity: A Survey of the Evidence from Firm-Level Data." World Economy 30 (1): 60-82.

Walter, Stefanie. 2015. "Globalization and the Demand-Side of Politics: How Globalization Shapes Labor Market Risk Perceptions and Policy Preferences." Political Science Research and Methods (forthcoming). doi:10.1017/psrm.2015.64.

Wilson, James Q. 1974. Political Organizations. Princeton, NJ: Princeton University Press.

World Bank. 2013. "World Bank Indicators.” http://data.worldbank.org /indicator (accessed March 7, 2016).

World Bank. 2015. "World Integrated Trade Solutions." http://wits.worldbank .org/ (accessed April 7, 2016).

WTO Secretariat. 2013. "Trade Policy Review: Costa Rica.” Trade Policy Review Body, World Trade Organization. https://www.wto.org/english /tratop_e/tpr_e/tp386_e.htm (accessed September 8, 2015). 